\title{
Aulonastus similis n. sp., a new quill mite species (Syringophilidae) parasitising passeriform birds (Tyrannidae and Cardinalidae) in Mexico
}

\author{
Lukasz Broda • Miroslawa Dabert • \\ Eliza Glowska
}

Received: 28 January 2016/ Accepted: 19 June 2016

(C) The Author(s) 2016. This article is published with open access at Springerlink.com

\begin{abstract}
A new quill mite species, Aulonastus similis n. sp. (Acariformes: Syringophilidae), parasitising Myiozetetes similis (Spix) (Tyrannidae) and Habia fuscicauda (Cabanis) (Cardinalidae) in Mexico is described and DNA barcode sequences of the mitochondrial cytochrome $c$ oxidase subunit I ( $\operatorname{cox} 1)$ and D1-D3 region of the nuclear 28S rRNA gene are provided. Morphologically, females of A. similis are close to A. euphagus Skoracki, Hendricks \& Spicer, 2010 but differ from this species in the length ratios of the idiosomal setae: ve:si (2-2.3:1 vs 1:1) and $f 2: f 1$ (4.7-6.3:1 vs 3.3:1).
\end{abstract}

\section{Introduction}

Mites of the family Syringophilidae (Acariformes: Cheyletoidea) are a highly diverse group of obligatory bird ectoparasites inhabiting the quills of a wide spectrum of hosts (Kethley 1970; Skoracki 2011).

L. Broda · E. Glowska $(\bowtie)$

Department of Animal Morphology, Faculty of Biology, Adam Mickiewicz University, Umultowska 89,

61-614 Poznan, Poland

e-mail: glowska@amu.edu.pl

M. Dabert

Molecular Biology Techniques Laboratory, Faculty of Biology, Adam Mickiewicz University, Umultowska 89, 61-614 Poznan, Poland
Currently, this family is represented by 334 species grouped into 60 genera which were recorded from 482 bird species (belonging to 95 families and 24 orders) (Glowska et al., 2015). The genus Aulonastus Kethley, 1970, so far has included 14 species parasitising 17 passeriform species belonging to ten families, Emberizidae (4 species), Motacillidae (3 spp.), Icteridae (2 spp.), Fringillidae (2 spp.), Troglodytidae (1 sp.), Laniidae (1 sp.), Turdidae (1 sp.), Cardinalidae (1 sp.), Prunellidae (1 sp.) and Rhinocryptidae (1 sp.) from Poland, Slovakia, Russia, Chile, Ecuador and the USA (Skoracki et al., 2010; Skoracki, 2011; Glowska et al., 2015).

For a long time, quill mites have been under an extensive taxonomic investigations based entirely on the external morphology (Kethley, 1970; Bochkov \& Mironov, 1999; Fain et al., 2000; Skoracki, 2011). However, recent application of molecular tools to syringophilids taxonomy has contributed to both, extending the standard of new species descriptions (Glowska et al., 2012a, b) and verification of compatibility between morphological and molecular delimitations of species boundaries (Glowska et al., 2013, 2014).

In the present paper, a new species of quill mite, Aulonastus similis n. sp., parasitising passerine birds of the families Tyrannidae (new host family for the genus) and Cardinalidae in Mexico (a new locality for Aulonastus spp.) is described using standard morphological data extended by the generation of novel DNA barcode sequences. 


\section{Materials and methods}

\section{Animal material}

Mites used in the study were collected from the body feathers of the social flycatcher Myiozetetes similis (Spix) (Tyrannidae) and the red-throated ant-tanager Habia fuscicauda (Cabanis) (Cardinalidae) in Mexico in 2008. Each covert was completely removed from the bird and dissected under an Olympus ZS30 stereomicroscope. Mites were preserved in $96 \%$ ethanol and, before mounting on microscopic slides, individually subjected to DNA extraction. Vouchers were mounted on slides in Faure's medium. Drawings were made with an Olympus $\mathrm{BH} 2$ microscope with differential interference contrast (DIC) optics and a camera lucida. All measurements and scale-bars in the figures are given in micrometres. The nomenclature for idiosomal setation is after Grandjean (1939) with modifications adapted for Prostigmata by Kethley (1990), and the nomenclature for leg setation is after Grandjean (1944). The application of these chaetotaxic schemes to Syringophilidae was recently provided by Bochkov et al. (2008) with changes by Skoracki (2011). Latin and common bird names follow Clements et al. (2014). The type-material is deposited in the following depositories: Adam Mickiewicz University, Poznań, Poland (AMU); Museum of Zoology of the University of Michigan, Ann Arbor, USA (UMMZ); Colección Nacional de Ácaros, Instituto de Biología, Universidad Nacional Autónoma de México (UNAM), Mexico (CNAC). The voucher material and the corresponding DNA samples are deposited in the collection of AMU under the identification numbers as indicated below.

\section{DNA isolation and sequencing}

Total genomic DNA was extracted from single specimens using DNeasy Blood \& Tissue Kit (Qiagen GmbH, Hilden, Germany) as described by Dabert et al. (2008). We generated sequences for the mitochondrial cytochrome $c$ oxidase subunit 1 ( $\operatorname{cox} 1)$ gene and a fragment comprising D1-D3 regions of the nuclear $28 \mathrm{~S}$ rRNA gene. Cox 1 was amplified by PCR with degenerate primers: Aseq01F (5'-GGA ACR ATA TAY TTT ATT TTT AGA-3') and Aseq03R (5'-GGA TCT CCW CCT CCW GAT GGA TT-3') (Glowska et al., 2014). PCR amplifications were carried out in 10 $\mu \mathrm{l}$ reaction volumes containing $5 \mu \mathrm{l}$ of Type-it Microsatellite Kit (Qiagen), $0.5 \mu \mathrm{M}$ of each primer, and $4 \mu \mathrm{l}$ of DNA template using a thermocycling profile of one cycle of $5 \mathrm{~min}$ at $95^{\circ} \mathrm{C}$ followed by $35 \mathrm{steps}$ of $30 \mathrm{~s}$ at $95^{\circ} \mathrm{C}, 1 \mathrm{~min}$ at $50^{\circ} \mathrm{C}, 1 \mathrm{~min}$ at $72^{\circ} \mathrm{C}$, with a final step of 5 min at $72^{\circ} \mathrm{C}$. Amplification of $28 \mathrm{~S}$ rDNA fragments was done with primers $28 \mathrm{~F} 0001\left(5^{\prime}\right.$-ACC CVC YNA ATT TAA GCA TAT-3') and 28R0990 (5'-CCT TGG TCC GTG TTT CAA GAC-3') (Mironov et al., 2012). After amplification, the PCR products were two-fold diluted with water, and $5 \mu \mathrm{l}$ of the sample was analysed by electrophoresis on a $1.0 \%$ agarose gel. Samples containing visible bands were purified with thermosensitive Exonuclease I and FastAP Alkaline Phosphatase (Fermentas, Thermo Scientific). Cox 1 amplicons were sequenced in one direction using the Aseq01F primer, and $28 \mathrm{~S}$ rDNA fragments were sequenced in two overlapping fragments using internal primers: sy28SF11 (5'-CAT TTT CAC TCT TCT CAT GC-3') and sy28SR12 (5'-AGC AAA GCA TAG TAC ACA TTT ATA-3') (Glowska et al., 2014). Sequencing was performed with BigDye Terminator v3.1 on an ABI Prism 3130XL Analyzer (Applied Biosystems, Foster City, CA, USA). Sequence chromatograms were checked for accuracy and edited using FinchTV 1.3.1 (Geospiza, Inc., Seattle, USA) and manually aligned in GeneDoc v.2.7.000 (Nicholas \& Nicholas, 1997). The sequences have been deposited in the GenBank database under accession nos. KU587037-KU587040.

\section{Results}

Family Syringophilidae Lavoipierre, 1953 Subfamily Syringophilinae Lavoipierre, 1953 Genus Aulonastus Kethley, 1970

\section{Aulonastus similis n. sp.}

Type-host: Myiozetetes similis (Spix) (Passeriformes: Tyrannidae), social flycatcher.

Other host: Habia fuscicauda (Cabanis) (Passeriformes: Cardinalidae), red-throated ant-tanager.

Type-locality: Los Tuxtlas Tropical Biological Station (UNAM), $18^{\circ} 35^{\prime} 7^{\prime \prime} \mathrm{N}, 95^{\circ} 4^{\prime} 31^{\prime \prime} \mathrm{W}$, Veracruz, Mexico. Type-material: Holotype female (UMMZ BMOC 15-0116-1), 13.v.2008, coll. S.V. Mironov (SVM 08-0513-6). Paratypes: three females (AMU-SYR. 1002.1-3, vouchers nos. EG 342, EG343, EG671), two females (UMMZ BMOC 15-0115-1a, b), three females (CNAC), same data as for the holotype. 

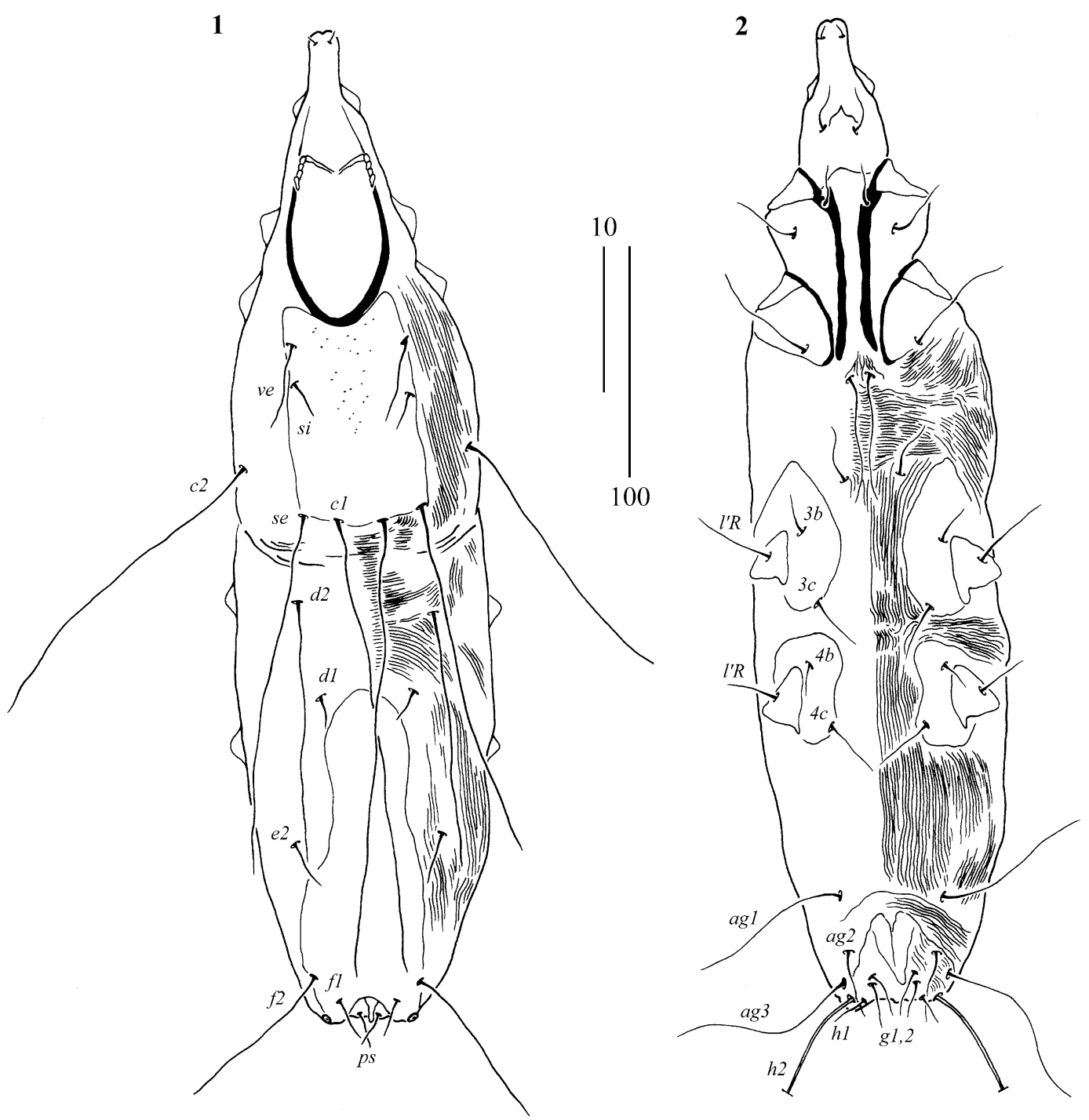

3

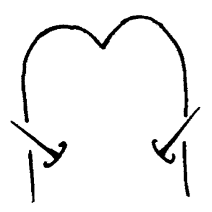

4

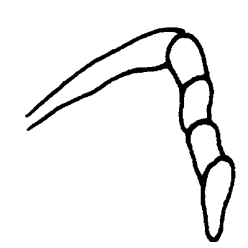

5

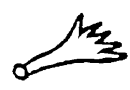

Figs. 1-5 Aulonastus similis n. sp., female. 1, Dorsal view; 2, Ventral view; 3, Hypostomal apex; 4, Peritremes; 5, Fan-like setae $p$ ' of leg IV. Scale-bars: 1, 2, $100 \mu \mathrm{m} ; 3-5,10 \mu \mathrm{m}$ 
Site on host: Quills of body feathers.

Voucher material: Three females from $H$. fuscicauda, collected at Los Tuxtlas Tropical Biological Station (UNAM), $18^{\circ} 35^{\prime} 7^{\prime \prime} \mathrm{N}, 95^{\circ} 4^{\prime} 31^{\prime \prime} \mathrm{W}$, Veracruz, Mexico, 1.v.2008, coll. S.V. Mironov (SVM 08-0501-3). All exoskeletons were lost during DNA extraction.

Representative DNA sequences. GenBank accession numbers for molecular voucher code EG 342 (ex typehost): KU587039 (coxl) and KU587037 (D1-D3); and for EG302 (ex H. fuscicauda): KU587040 (cox1) and KU587038 (D1-D3).

Etymology: The specific name is taken from the specific name of the type-host.

Description (Figs. 1-5)

Female [Based on the holotype and 7 paratypes (range in parentheses).] Total body length 410 (380-435). Gnathosoma. Infracapitulum apunctate. Each transverse branch of peritremes with 1 long chamber, each longitudinal branch with 4-5 chambers (Fig. 4). Stylophore apunctate, 120 (120-125) long. Movable cheliceral digit (90) long. Idiosoma. Propodonotal shield well sclerotised, bearing bases of setae ve, si, se and $c 1$, its antero-median part punctate. Length ratio of setae ve:si 2-2.3:1. Hysteronotal shield fused to pygidial shield, unstriated and apunctate. Length ratios of setae $d 2: d 1$ 5.5-7:1, d1:e2 1:1-2, fl:hl 1:1-1.2, f2:h2 1:2.4-3.4, ag1:ag2:ag3 1.6-1.7:1:2.12.3. Setae $f 2$ 4.7-6.3 times longer than $f 1$. Setae $h 2$ $12-16$ times longer than $h l$. Genital setae subequal in length. Genital setae $g 1,2$ equal or slightly (1.3 times) longer than pseudanal setae psl. Setae $3 c 1.2$ times longer than $3 b$. Coxal fields I-IV delicately punctate or apunctate. Cuticular striations as in Figs. 1-2. Legs. Fan-like setae $p$ ' and $p$ " with 5 tines (Fig. 5). Setae $t c$ " of legs III-IV 1.5 times longer than $t c$ '. Lengths of setae: ve 20 (right)/30 (left) (35-40); si 15 (15-20); se (140-155); c1 180 (195-220); c2 (125-145); dl 15 (20); d2 (105-140); e2 25 (20); f1 15 (15); f2 70 (95); hl 15 (20); h2 240 (215-230); psl 15 (20); g1, 220 (15-20); ag1 50 (55-80); ag2 30 (40); ag3 70 (85-105); l'RIII 20 (30); l'RIV 20 (20); tc'III-IV 20; tc"III-IV 30; 3b 15; 3c 20.

DNA barcodes

We sequenced $609 \mathrm{bp}$ of the $5^{\prime}$-terminus of the $\operatorname{cox} 1$ gene and 1,148 bp comprising D1-D3 region of $28 \mathrm{~S}$
rDNA for three specimens collected from Myiozetetes similis and three specimens collected from Habia fuscicauda. The cox 1 sequences revealed two different haplotypes specific for each population. They vary in one nucleotide position leading to no amino acid substitution. The conspecific status of both populations (from M. similis and H. fuscicauda) is also supported by the 28S rRNA gene fragment because all analyzed specimens showed no variation.

\section{Remarks}

The new species is morphologically most similar to Aulonastus euphagus Skoracki, Hendricks \& Spicer, 2010, described from the Brewer's blackbird Euphagus cyanocephalus (Wagler) (Passeriformes: Icteridae) in the USA (Skoracki et al., 2010). In females of both species, the transverse and longitudinal branches of the peritremes are represented by 1 and $4-5$ chambers, respectively, the propodonotal shield is punctate, the unstriated hysteronotal shield is fused to the pygidial shield, genital setae are subequal in length and coxal fields I-IV are delicately punctate or without punctation. Females of A. similis n. sp. differ from $A$. euphagus in the length ratios of setae ve:si 2-2.3:1 and $f 2: f 1$ 4.7-6.3:1. In females of A. euphagus, setae ve and $s i$ are subequal in length and the length ratio of setae $f 2: f 1$ is $3.3: 1$.

The presence of $A$. similis n. sp. on two phylogenetically distant hosts belonging to different passerine suborders (Passeri and Tyranni) suggests a distribution resulting from horizontal transfer between two host species rather than cophylogenetic processes.

Acknowledgements We are very grateful to Dr. Sergey V. Mironov (Russian Academy of Sciences, Moscow, Russia) and Dr. Pavel Klimov (Museum of Zoology of the University of Michigan, Ann Arbor, USA) who collected the material and made it available to our research.

Funding The field expedition was supported by the grant from the US National Science Foundation (DEB-0613769) to Prof. Barry M. OConnor (Museum of Zoology, University of Michigan, Ann Arbor, USA).

\section{Compliance with ethical standards}

Conflict of interest The authors declare that they have no conflict of interest. 
Ethical approval All applicable institutional, national and international guidelines for the care and use of animals were followed. The collection of mites in Mexico was made under the license No FAUT-0209 issued by the Dirección General de Vida Silvestre (Mexico).

Open Access This article is distributed under the terms of the Creative Commons Attribution 4.0 International License (http:// creativecommons.org/licenses/by/4.0/), which permits unrestricted use, distribution, and reproduction in any medium, provided you give appropriate credit to the original author(s) and the source, provide a link to the Creative Commons license, and indicate if changes were made.

\section{References}

Bochkov, A. V., \& Mironov, S. V. (1999). New quill mite species of the family Syringophilidae (Acari: Cheyletoidea) from the European part of Russia. Acarina, 7 , $35-45$.

Bochkov, A. V., OConnor, B. M., \& Wauthy, G. (2008). Phylogenetic position of the family Myobiidae within the Prostigmata (Acari: Acariformes). Zoologischer Anzeiger, 247, 15-45.

Clements, J. F., Schulenberg, T. S., Iliff, M. J., Roberson, D., Fredericks, T. A., Sullivan, B. L., \& Wood, C. L. (2014). The eBird/Clements checklist of birds of the world: Version 6.9. Downloaded from http://www.birds.cornell.edu/ clementschecklist/download/ (accessed 28 January 2016).

Dabert, J., Ehrnsberger, R., \& Dabert, M. (2008). Glaucalges tytonis sp. n. (Analgoidea, Xolalgidae) from the barn owl Tyto alba (Strigiformes, Tytonidae): compiling morphology with DNA barcode data for taxon descriptions in mites (Acari). Zootaxa, 1719, 41-52.

Fain, A., Bochkov, A. V., \& Mironov, S. V. (2000). New genera and species of quill mites of the family Syringophilidae (Acari: Prostigmata). Bulletin de l'Institut Royal des Sciences Naturelles de Belgique, 70, 33-70.

Glowska, E., Dragun-Damian, A., \& Dabert, J. (2012a). Picobia dziabaszewskii sp. nov. (Acari, Syringophilidae) - combined description (morphology with DNA barcode data) of a new quill mite species parasitizing Garrulax formosus (Passeriformes: Leiothrichidae). Zootaxa, 3224, 57-61.

Glowska, E., Dragun-Damian, A., \& Dabert, J. (2012b). A new quill mite Syringophiloidus pseudonigritae sp. nov.
(Prostigmata, Syringophilidae) parasitizing Pseudonigrita arnaudi (Passeriformes, Ploceidae) - a combined description using morphology and DNA barcode data. Zootaxa, 3532, 64-68.

Glowska, E., Dragun-Damian, A., \& Dabert, J. (2013). DNAbarcoding contradicts morphology in quill mite species Torotrogla merulae and $T$. rubeculi (Prostigmata: Syringophilidae). Folia Parasitologica, 60, 51-60.

Glowska, E., Dragun-Damian, A., Broda, L., Dabert, J., \& Dabert, M. (2014). DNA barcodes reveal female dimorphism in syringophilid mites (Actinotrichida: Prostigmata: Cheyletoidea): Stibarokris phoeniconaias and $\mathrm{Ci}$ conichenophilus phoeniconaias are conspecific. Folia Parasitologica, 61, 272-276.

Glowska, E., Chrzanowski, M., \& Kaszewska, K. (2015). Checklist of the Quill mites (Acariformes: Syringophilidae) of the World. Zootaxa, 3968, 1-81.

Grandjean, F. (1939). Les segments postlarvaires de l'hysterosoma chez les oribates (Acariens). Bulletin de la Société Zoologique de France, 64, 273-284.

Grandjean, F. (1944). Observations sur les acariens de la famille Stigmaeidae. Archives des Sciences Physiques et Naturelles, 26, 103-131.

Kethley, J. B. (1970). A revision of the family Syringophilidae (Prostigmata: Acarina). Contributions of the American Entomological Institute, 5, 1-76.

Kethley, J. B. (1990). Acarina: Prostigmata (Actinedida). In: Dindal, D. L. (Ed.) Soil Biology Guide. New York: Wiley \& Sons, pp. 667-754.

Mironov, S. V., Dabert, J., \& Dabert, M. (2012). A new feather mite species of the genus Proctophyllodes Robin,1877 (Astigmata, Proctophyllodidae) from the long-tailed tit Aegithalos caudatus (Passeriformes: Aegithalidae) morphological description with DNA barcode data. Zootaxa, 3253, 54-61.

Nicholas, K. B., \& Nicholas, Jr H. B. (1997). GeneDoc: a tool for editing and annotating multiple sequence alignments. Pittsburgh Supercomputing Center's National Resource for Biomedical Supercomputing, ver. 2.7.000. http://www. nrbsc.org/downloads (accessed 2 March 2007).

Skoracki, M. (2011). Quill mites (Acari: Syringophilidae) of the Palaearctic region. Zootaxa, 2840, 1-414.

Skoracki, M., Hendricks, S., \& Spicer, G. (2010). Four new species of Aulonastus Kethley, 1970 (Acari: Syringophilidae) from North American passerines. Systematic Parasitology, 76, 131-144. 